\title{
ISOLASI BAKTERI INDIGEN SEBAGAI PENDEGRADASI BAHAN ORGANIK PADA MEDIA PEMBENIHAN IKAN LELE DUMBO (Clarias SP.) SISTEM RESIRKULASI TERTUTUP
}

\section{ISOLATION INDIGEN BACTERIA IN ORGANIC MATERIALS AS MEDIA DEGRADING SEEDLING FISH CATFISH (Clarias sp.) CLOSED RECIRCULATION SYSTEM}

\author{
Muhammad Arief, Laksmi Sulmartiwi, Prayogo dan Herlina Maya Saputri \\ Fakultas Perikanan dan Kelautan Universitas Airlangga \\ Kampus C Mulyorejo - Surabaya, 60115 Telp. 031-5911451
}

\begin{abstract}
Rearing of African catfish fry requires an abundant water supply, so this causes Clarias gariepinus hatchery operations difficult in areas that lack water, so use a closed recirculation system technology which is an attempt to tackle the problem of limited water in an area for hatchery operations. However, these systems have drawbacks which deposition of organic materials on water quality pond maintenance reduced the need for water quality management. Components of organic materials is a source of water quality pollutants consisting of proteins, lekam, and carbohydrates, so that in the organic material needed pendegradasian existence of groups of bacteria and proteolytic bacteria, lipolytic, and amylolitic. The results of this study show that in the media of African catfish hatchery fish have bacteria that degrade organic material that has properties of proteolytic, lipolytic, and most potentially amylolitic consisting of bacterial isolates of Pseudomonas stutzeri B ie $(97.81 \%)$ with values highest protease hydrolysis test results $1.878 \mathrm{~mm}$, ie $\mathrm{G}$ isolates of Pseudomonas pseudomallei (97.81\%) with the highest value of 1.909 $\mathrm{mm}$ hydrolysis test and bacterial isolates of Pseudomonas stutzeri K $(61.21 \%)$ with the highest value of $1.944 \mathrm{~mm}$ hydrolysis test.
\end{abstract}

Keywords : Pseudomonas, Clarias sp., indigen bacteria

\section{Pendahuluan}

Ikan lele dumbo (Clarias sp)

merupakan komoditas air tawar yang sudah dikenal dikalangan masyarakat dan sangat populer serta mempunyai pasar yang baik. Budidaya ikan lele dumbo (Clarias sp), akhirakhir ini semakin mendapat perhatian dan mulai berkembang di Indonesia, terutama karena mempunyai nilai ekonomis tinggi, mudah dipelihara dan dapat tumbuh dengan cepat (Prihartono, dkk, 2000). Usaha pembenihan ikan lele dumbo umumnya terbatas pada daerah sentra pembenihan yang memiliki potensi sumber air melimpah. Hal ini menyebabkan kendala bagi kegiatan budidaya ikan lele dumbo pada daerah yang minim air khususnya pada tahap pembenihan. Mengatasi masalah terbatasnya air tersebut, muncul suatu teknologi sistem pembenihan dengan mengoptimalkan pemanfaatan air yang disebut dengan teknologi sistem resirkulasi tertutup. Sistem resirkulasi tertutup merupakan suatu teknologi pemanfaatan air secara terus-menerus tanpa ada pergantian air selama proses budidaya, namun dalam sistem ini juga memiliki kelemahan yaitu menumpuknya bahan organik yang berasal dari sisa pakan dan feses (Sasongko,2001).
Mengatasi masalah yang timbul pada sistem resirkulasi tertutup ini diupayakan suatu metode penambahan bakteri pada pembenihan ikan lele dumbo sistem resirkulasi tertutup dengan memanfaatkan kemampuan bakteri dalam mendegradasi bahan organik. Menurut Droste (1997), bahan organik yang merupakan sumber bahan pencemar kualitas air umumnya adalah bahan organik yang terdiri dari protein, lemak dan karbohidrat sehingga dalam pendegradasian bahan organik tersebut diperlukan adanya bakteri dari golongan bakteri proteolitik, bakteri lipolitik dan bakteri amilolitik. Berdasarkan pemanfaatan dari bakteri pendegradasi maka perlu dikaji mengenai peranan bakteri pendegradasi bahan organik pada sistem resirkulasi tertutup. Hasil kajian bakteri yang didapat dari hasil identifikasi tersebut merupakan spesies bakteri indigen yang dapat digunakan untuk memperbaiki kualitas air. Bakteri indigen adalah bakteri yang berasal dari habitatnya sendiri sehingga kondisi lingkungannya sesuai dengan syarat hidupnya, hal ini bertujuan agar bakteri tersebut dapat tetap tumbuh dan berkembangbiak atau memperbanyak diri dengan mudah karena tidak perlu menyesuaikan diri lagi dengan lingkungannya. 


\section{Materi dan Metode Penelitian \\ Tempat dan Waktu Penelitian}

Penelitian ini dilaksanakan pada bulan Januari 2010 di Laboratorium Biologi Fakultas Sains dan Teknologi, Universitas Airlangga, Surabaya.

\section{Metode Penelitian}

Penelitian ini berupa observasi mengenai karakteristik isolat bakteri indigen yang mempunyai kemampuan untuk mendegradasi bahan organik. Metode penelitian yang digunakan adalah deskriptif-eksploratif dengan teknik observasi.

\section{Obyek Penelitian}

Objek dalam penelitian ini ialah sample air pada kolam pemeliharaan ikan lele dumbo (Clarias sp) sistem resirkulasi tertutup di Desa Ploso Wahyu Kecamatan Lamongan Kabupaten Lamongan. Kolam sistem resirkulasi tertutup tersebut menggunakan komponen filter berupa batu zeolit, arang dan ijuk yang merupakan filter kimia dan fisika. Sumber air yang digunakan berasal dari air PDAM Kab.Lamongan.

\section{Alat Penelitian}

Alat-alat yang digunakan dalam penelitian ini antara lain: botol sampel (water sampler) termos es, autoclave, timbangan analitik digital, mikroskop, gelas ukur, labu Erlenmeyer, beaker glass, tabung reaksi, pipet mikro, petri disk, kawat ose, bunsen, spatula, objek glass, dan cover glass. Kelengkapan identifikasi dilakukan menggunakan alat Microbact $^{T M}$ GNB 12A/B/E, $24 E$ Identification Kits.

\section{Bahan Penelitian}

Bahan yang digunakan berupa sampel air dari pembenihan ikan lele dumbo (Clarias sp) sistem resirkulasi tertutup di Desa Ploso Wahyu Kecamatan Lamongan Kabupaten Lamongan. Bahan lain yang digunakan adalah berupa media selektif untuk menumbuhkan bakteri. Media selektif yang digunakan adalah media Bushnell Haas (BH) ditambah $1 \%$ olive oil yang digunakan untuk mengisolasi bakteri pengurai lemak. Media $\mathrm{BH}$ ditambah $1 \%$ amilum yang digunakan untuk mengisolasi bakteri pengurai amilum. Media $\mathrm{BH}$ ditambah $1 \%$ susu skim yang digunakan untuk mengisolasi bakteri pengurai protein.

Tahap pengambilan sampel.

Pengambilan sample air menggunakan botol steril yang dilengkapi dengan tutup, dan bervolume $250 \mathrm{ml}$. Pengambilan sampel dilakukan secara aseptik untuk mencegah kontaminasi bakteri dari luar. Sebelum pengambilan sampel air kolam pembenihan terlebih dahulu dilakukan pengukuran kualitas air untuk memastikan bahwa kualitas air pada kolam pembenihan ikan lele dumbo optimal. Sampel kolam pembenihan diambil pada 5 titik berbeda yang dianggap dapat mewakili kondisi kolam pembenihan secara keseluruhan. Perlakuan selanjutnya yaitu isolasi, sebelum pengambilan sampel air untuk tahap isolasi, air sampel yang sudah diambil dan dimasukkan dalam botol dihomogenisasikan terlebih dahulu setelah itu diambil $1 \mathrm{ml}$ sampel air untuk digunakan pada tahap selanjutnya yaitu isolasi.

\section{Tahap isolasi.}

Tahap isolasi bakteri merupakan salah satu cara untuk mendapatkan jenis bakteri yang diinginkan. Isolasi merupakan kegiatan pemisahan mikroorganisme yang akan diuji dari mikroorganisme lain dengan menggunakan media selektif, sehingga diharapkan akan diperoleh biakan atau kultur murni (Benson, 1998). Sampel air yang sudah disiapkan mulamula dilakukan pengenceran untuk mengetahui jenis bakteri yang terdapat dalam sample air tersebut. Pengenceran dilakukan dengan cara mengambil $1 \mathrm{ml}$ sample air kemudian diencerkan pada tabung tersendiri, dari pengenceran ini kemudian diambil $1 \mathrm{ml}$ untuk diencerkan lagi. Langkah selanjutnya adalah dari pengenceran tersebut diambil $0,1 \mathrm{ml}$ untuk disebarkan pada suatu media agar Bushnell Haas (BH) yang telah ditambahkan amilum, susu skim, dan olive oil sebagi indikator kerja bakteri kemudian diinkubasi pada suhu kamar yaitu $27^{\circ} \mathrm{C}$ selama $1-2$ x 24 jam untuk mendapatkan beberapa koloni bakteri yang terdapat dalam sample. Hal ini sesuai dengan yang dikemukakan (Ashdown, 1979), bahwa proses isolasi bakteri yang dilakukan untuk mengetahui kemampuan bakteri dalam mendegradasi maupun menghidrolisis dapat dilakukan pada media selektif yang telah ditambah dengan indikator kerja bakteri. Proses isolasi bakteri ini bertujuan agar kerja bakteri lebih efisien jika diisolasi pada media selektif yang sesuai dengan tempat hidupnya (Darmayasa, 2008). Kemudian beberapa jenis bakteri yang ditemukan diambil sedikit dari koloni bakteri tersebut dengan ose yang sudah disterilkan terlebih dahulu untuk digunakan pada tahap selanjutnya yaitu tahap pengukuran uji hidrolisis.

\section{Tahap pengukuran uji hidrolisis.}

Uji hidrolisis ini dilakukan untuk mengetahui bakteri yang berpontensi paling kuat dalam menghidrolisis protein, lemak dan karbohidrat. Koloni bakteri yang tumbuh terisolasi dengan memiliki karakter pengurai dapat ditunjukkan oleh terbentuknya zona bening di sekitar pertumbuhannya. Potensi 
hidrolisis dari setiap isolat dapat dihitung berdasarkan nisbah diameter zona bening terhadap diameter koloni bakteri yang tumbuh. Semakin besar halo yang terbentuk maka bakteri tersebut memiliki potensi paling tinggi dalam mendegradasi bahan organik (Suarsini, 2006).

Sampel bakteri yang diambil dari beberapa koloni yang terbentuk kemudian disebarkan pada media agar Bushnell Haas (BH) yang sudah ditambah dengan olive oil sebagai media bakteri untuk mendegradasi lemak, media agar Bushnell Haas (BH) yang sudah ditambah dengan susu skim sebagai media bakteri untuk mendegradasi protein dan media agar Bushnell Haas (BH) yang sudah ditambah dengan amilum sebagai media bakteri untuk mendegradasi karbohidrat kemudian diinkubasi pada suhu ruangan yaitu $27^{\circ} \mathrm{C}$ selama 1-2 x 24 jam untuk mengetahui kerja bakteri dalam mendegradasi bahan organik, dari tahap ini akan didapatkan bakteri yang paling berpotensi dalam mendegradasi bahan organik, hal ini ditunjukkan dengan terbentuknya suatu halo atau zona bening disekeliling koloninya.

\section{Tahap Eksplorasi}

Eksplorasi bakteri dilakukan untuk mengetahui peranan bakteri yang berhasil diisolasi dari perairan. Tahap eksplorasi meliputi beberapa uji didasarkan antara lain:

\section{a. Morfologi koloni bakteri}

Pengamatan morfologi koloni bakteri menurut Barrow (2002) dilakukan dengan tujuan untuk mengetahui bentuk, ukuran, tekstur, dan warna koloni bakteri dengan cara mencatat bentuk, ukuran, tekstur, dan warna sesuai acuan identifikasi. Pada tahap ini pertama ambil sedikit sampel bakteri dengan menggunakan ose yang sudah disterilkan terlebih dahulu pada isolat bakteri yang paling berpotensi yang ditemukan dan diletakkan pada obyek glass setelah itu difiksasi diatas api bunsen hingga kering kemudian ditutup dengan cover glass dan diamati dibawah mikroskop dengan pembesaran 400 kali.

\section{b. Morfologi bakteri}

Sebelum kegiatan pengamatan untuk mengetahui morfologi bakteri pertama diawali dengan pewarnaan Gram menurut prosedur Saanin (1984) caranya dengan mengambil satu ose dari setiap jenis koloni dari media isolasi, dan dibuat ulasan di atas objek glass. Pengecatan gram dengan menggunakan pewarna gram A (larutan ammonium oksalat kristal violet) dibiarkan selama 2 menit dan sisa zat warna dibuang dengan menggunakan air mengalir, gram B (larutan iodium lugol) dibiarkan selama 1 menit kemudian sisa larutan iodium lugol dicuci dengan menggunakan air mengalir, gram $\mathrm{C}$ (larutan asam aseton alkohol) dibiarkan selama 10-20 detik kemudian dicuci di bawah air mengalir, dan gram D (larutan safranin) dibiarkan selama 30 detik kemudian dicuci dengan air mengalir dan dikeringkan dengan menggunakan kertas saring. Sebelum diamati di bawah mikroskop dengan pembesaran 400x, preparat terlebih dahulu ditetesi dengan minyak emersi sebanyak 1-2 tetes.

Hasil pewarnaan diamati dibawah mikroskop. Sel yang telah melalui pengecatan gram jika bersifat gram positif maka sel berwarna biru gelap atau ungu dan bila gram negatif berwarna merah muda. Hasil karakterisasi dirujuk menggunakan buku acuan Bergey's Manual of Determinative Bacteriology dan dirujuk melalui referens International Journal of Systematic Bacteriology (USB)/ International Journal of Systematic and Evolutionary Microbiology (USEM) yang sudah diolah dengan program software dari Microbact $^{\mathrm{TM}}$.

\section{Hasil dan Pembahasan}

Hasil dari isolat bakteri indigen yang berasal dari pembenihan ikan lele dumbo sistem resirkulasi tertutup sebagai bakteri pendegradasi bahan organik pada media selektif Bushnell Haas (BH) yang telah ditambahkan dengan amilum, susu skim, dan olive oil sebagai indikator kerja bakteri ditemukan beberapa jenis isolat bakteri yang kemudian dikelompokkan menjadi 11 isolat bakteri yang dibedakan berdasarkan morfologi koloni serta warna isolat bakteri tersebut. 11 isolat bakteri yang ditemukan terdiri dari 3 isolat bakteri yang didapat dari media elektif yang ditambah dengan amilum, 4 isolat bakteri yang berasal dari media selektif yang ditambah dengan olive oil, dan 4 isolat bakteri yang berasal dari media selektif yang ditambah dengan susu skim. Masing-masing bakteri tersebut di inokulasi pada media selektif Bussnell Hass $(\mathrm{BH})$ dengan penambahan protein, lemak dan amilum sebagai indikator kerja bakteri.

Tahap selanjutnya yaitu uji hidrolisis, dari uji hidrolisis tersebut ditemukan tiga isolat bakteri yang paling berpotensi dalam mendegradasi bahan organik, hasil tersebut didapatkan dari pengukuran diameter halo yang 


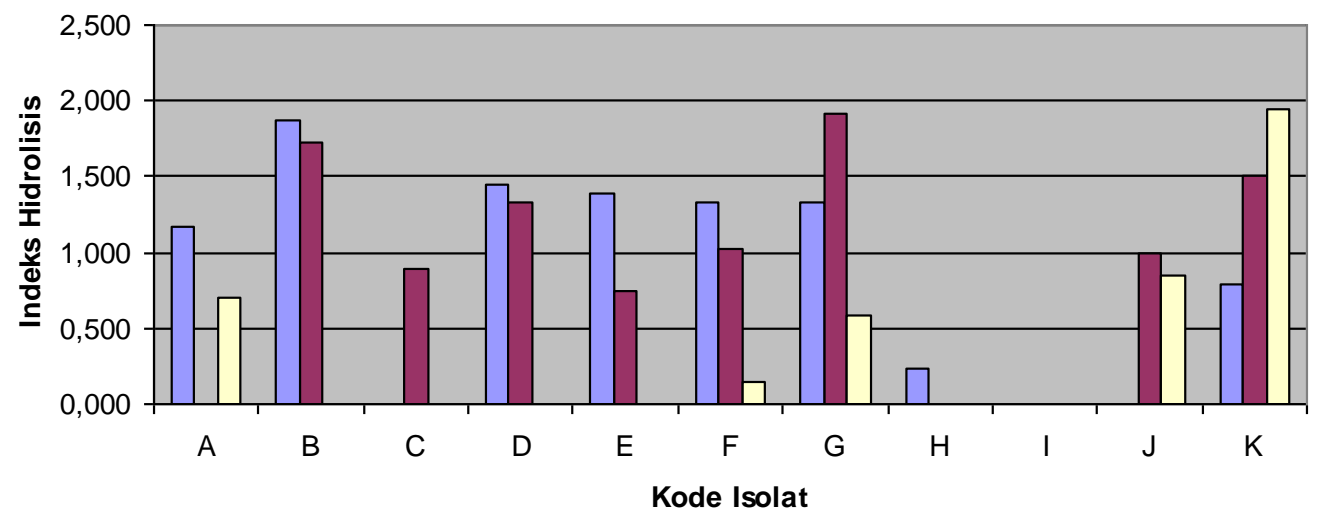

$\square$ Protease $\square$ Lipase $\square$ Amilase

Nilai Rata-rata Hidrolisis Bakteri pada Media Pembenihan Ikan Lele Dumbo (Clarias sp) Sistem Resirkulasi Tertutup

Keterangan :

$\mathrm{A}, \mathrm{B}$ dan $\mathrm{C}=$ isolat dari media yang ditambahkan amilum

$\mathrm{D}, \mathrm{E}, \mathrm{F}$ dan $\mathrm{G}=$ isolat dari media yang ditambahkan lemak

$\mathrm{H}, \mathrm{I}, \mathrm{J}$ dan $\mathrm{K}$ = isolat dari media yang ditambahkan protein

terbentuk akibat kerja bakteri tersebut. Hasil uji hidrolisis dari 11 isolat bakteri yang ditemukan dapat dilihat pada Tabel 1. dari 11 bakteri yang di uji hidrolisis didapatkan tiga bakteri yang diduga paling berpotensi dalam mendegradasi bahan organik.

Hasil dari ketiga isolat yang diduga paling berpotensi dalam mendegradasi bahan organik tersebut terdiri dari bakteri amilolitik yang meliputi A, B, dan C, bakteri lipolitik yang meliputi D, E, F dan G, serta bakteri proteolitik yang meliputi H, I, J, dan K. Dilihat dari masing-masing nilai hidrolisis, ditunjukan bahwa masing-masing isolat memiliki nilai hidrolisis yang bervariasi. Kemampuan bakteri dalam mendegradasi bahan organik diketahui dari besarnya halo yang terbentuk. Semakin besar halo yang terbentuk maka bakteri tersebut semakin berpotensi tinggi dalam mendegradasi bahan organik yang terdiri dari protein, lemak, dan karbohidrat. Berdasarkan gambar 3 ditunjukan bahwa nilai hidrolisis protease tertinggi terdapat pada isolat bakteri amilolitik B sebesar 1,878, nilai hidrolisis lipase tertinggi terdapat pada isolat bakteri lipolitik G sebesar 1,909, sedangkan nilai hidrolisis amilase tertinggi terdapat pada isolat bakteri proteolitik K sebesar 1,944.

Hasil dari uji hidrolisis ditemukan isolat bakteri yang paling berpotensi sebagai pendegradasi bahan organik yaitu bakteri dengan kode B, G, dan K. Ketiga isolat tersebut dieksplorasi dengan cara mengetahui sifat morfologi koloni bakteri, morfologi bakteri dan sifat fisiologi dengan menggunakan Microbact ${ }^{\mathrm{TM}}$ GNB 12A/B/E, 24 E Identification Kits. Salah satu tahap yang dilakukan untuk mengetahui morfologi bakteri yaitu pewarnaan. Hasil pewarnaan gram dari ketiga isolat bakteri menunjukkan bahwa ketiga bakteri tersebut merupakan bakteri gram negatif yang ditunjukkan dari hasil pewarnaan yang berwarna merah muda.

Berdasarkan hasil dari pengamatan sifat morfologi ketiga isolat bakteri tersebut dengan menggunakan Microbact TM GNB 12A/B/E, 24 E Identification Kits didapatkan bahwa dari tiga isolat bakteri B merupakan bakteri Pseudomonas stutzeri (indeks kesamaan 97,81\%), bakteri G merupakan bakteri Pseudomonas pseudomallei (indeks kesamaan 97,81\%) dan bakteri K merupakan bakteri Pseudomonas stutzeri (indeks kesamaan $61,21 \%$ ) termasuk bakteri gram negatif karena dinding sel bakteri tersebut sebagian besar terdiri dari peptidoglikan

Hasil dari ketiga isolat yang diduga paling berpotensi mendegradasi bahan organik yang terdiri dari protein, lemak, dan karbohidrat ditunjukkan pada besarnya diameter halo pada media selektif Bushnall Hass (BH) yang telah ditambahkan susu skim sebagai indikator pendegradasi protein, olive oil sebagai indikator pendegradasi lemak, dan amilum sebagai 
indikator pendegradasi karbohidrat yaitu inokulan bakteri $\mathrm{B}, \mathrm{G}, \mathrm{K}$ sehingga dapat menunjukkan bahwa bakteri tersebut dapat tumbuh dan berkembang dengan uji hidrolisis. Menurut Madigan et al., (2003) bahwa Indeks hidrolisis merupakan gambaran terselenggaranya reaksi enzimatis yang diproduksi oleh bakteri pendegradasi bahan organik. Berdasarkan kandungan bahan organik yang terdapat pada pembenihan ikan lele dumbo sistem resirkulasi tertutup maka proses pendegradasian bahan organik yang terjadi adalah pendegradasian bahan organik meliputi protein, lemak dan karbohidrat (Droste, 1997).

Isolat $\mathrm{K}$ merupakan isolat bakteri yang mampu mendegradasi karbohidrat yang paling tinggi pada media Bushnell Hass (BH) yang telah ditambah amilum sebagai indikator kerja bakteri dengan bantuan enzim amilase yang dihasilkan oleh bakteri. Hal ini di tunjukkan dengan terbentuknya halo yang paling besar. Fardiaz (1993) menyatakan bahwa bakteri yang tergolong amilolitik adalah bakteri yang memproduksi enzim amilase. Enzim amilase berfungsi untuk memecah pati atau glikogen dan hasil akhir dari pemecahan pati ini menghasilkan glukosa atau maltosa. Isolat B merupakan isolat bakteri yang mampu mendegradasi protein yang paling tinggi pada media Bushnell Hass (BH) yang telah ditambahkan susu skim sebagai indikator kerja bakteri dengan bantuan enzim proteinase yang dihasilkan oleh bakteri tersebut hal ini di tunjukkan besarnya halo yang terbentuk. Menurut Budiyanto (2002), bakteri proteolitik merupakan bakteri penghasil enzim proteinase yang memiliki kemampuan dalam menghidrolisis protein. Enzim protease dapat mengubah protein menjadi peptida dan mengubahnya menjadi bentuk yang lebih sederhana yaitu asam amino.

Isolat $\mathrm{G}$ merupakan isolat bakteri yang mampu mendegradasi lemak pada media Bushnell Hass (BH) yang telah ditambahkan olive oil sebagi indikator kerja bakteri dengan bantuan enzim lipase yang dihasilkan oleh bakteri tersebut hal ini di tunjukkan dengan adanya halo yang paling besar. Semakin besar halo yang terbentuk maka bakteri tersebut memiliki kemampuan untuk mendegradasi bahan organik yang paling kuat. Menurut Sexena, et.al (2004) bakteri lipolitik merupakan bakteri penghasil enzim lipase yang memiliki kemampuan untuk menghidrolisis triasilgliserol menjadi asam lemak dan gliserol.

Ketiga isolat tersebut kemudian dieksplorasi dengan cara mengetahui sifat morfologi koloni bakteri, morfologi bakteri dan sifat fisiologi dengan menggunakan Microbact ${ }^{\mathrm{TM}}$ GNB 12A/B/E, 24 E Identification Kits. Isolat B ditemukan spesies Pseudomonas stutzeri (dengan indeks kesamaan 97,81\%), G ditemukan spesies Pseudomonas pseudomallei (dengan indeks kesamaan 97,81\%), dan K ditemukan spesies Pseudomonas stutzeri (dengan indeks kesamaan 61,21\%). Perbedaan antara Pseudomonas stutzeri dan Pseudomonas pseudomallei yaitu bentuk morfologi koloni dari bakteri tersebut. Klasifikasi Pseudomonas sp, Pseudomonas pseudomallei, dan Pseudomonas stutzeri dapat diklasifikasikan sebagai berikut:

$\begin{array}{ll}\text { Kingdom } & \text { : Monera } \\ \text { Divisi } & \text { : Schizophyta } \\ \text { Kelas } & \text { : Schyzomyetes } \\ \text { Ordo } & \text { : Pseudomonadales } \\ \text { Famili } & : \text { Pseudomonadaceae } \\ \text { Genus } & : \text { Pseudomonas } \\ \text { Spesies } & : \text { Pseudomonas sp (Salle, 1991) } \\ & : \text { Pseudomonas pseudomallei } \\ & \text { (Salle, 1991) } \\ & \text { Pseudomonas stutzeri (Salle, } \\ & \text { 1991) } \\ & \text { Pseudomonas merupakan bakteri yang }\end{array}$ penting dalam dekomposisi secara aerobik dan biodegradasi karena memegang peranan penting dalam siklus karbon. Pseudomonas adalah bakteri berbentuk batang yang berukuran 0.5$0.8 \mu \mathrm{m}$ respirasi secara aerobik dan bergerak dengan falgella polar dan bersifat gram negatif (Irianto, 2005). Hal ini sesuai dengan yang dikemukakan Inglis (2006), yang menyatakan bahwa umumnya bakteri Pseudomonas merupakan bakteri yang bersifat gram negatif dan berbentuk basil. Bakteri Pseudomonas termasuk golongan bakteri mesofil, bakteri tersebut dapat tumbuh optimal pada kisaran 25 $-30^{\circ} \mathrm{C}$ dengan suhu optimum $40^{\circ} \mathrm{C}$ (Roberts, 1989).

\section{Kesimpulan}

Karakteristik bakteri Pseudomonas pseudomallei dapat tumbuh optimal pada suhu $27^{\circ} \mathrm{C}$, selnya berdiameter $0,8 \mu \mathrm{m}$ dengan panjang $1,5 \mu \mathrm{m}$ dan memiliki flagel satu atu lebih (Ashdown, 1979). Pseudomonas stutzeri dapat dibedakan dari Pseudomonas yang lain dengan menggunakan berbagai karakteristik morfologi koloni, gram negatif, bentuk batang dan motil dengan sebuah alat flagela polar tunggal. Karakteristik bakteri Pseudomonas stutzeri dapat tumbuh optimal pada suhu $27^{\circ} \mathrm{C}$, selnya berdiameter $0,5 \mu \mathrm{m}$ dengan panjang 1,3 $\mu \mathrm{m}$ dan memiliki 1 flagel namun pada kondisi tertentu bakteri Pseudomonas stutzeri dapat menghasilkan flagel. 


\section{Daftar Pustaka}

Ashdown, L. R. 1979. Identification of Pseudomonas pseudomallei in The Clinical Laboratory. http://www.journalof-clinical-pathology.com.04/05/2010.5pp.

Barrow, G.I and R.K.A. Feltham.2002. Cowan and Steels Manual for The Identifikation of Medical Bakteria. Chambridge Uiversity Press.

Boyd, C.E. 1992. Water Quality In Ponds For Aquaculture. Bermingham Publishing Co Bermingham, Alabama.

Darmayasa., I. B.G. 2008. Isolasi Dan Identifikasi Bakteri Pendegradasi Lipid (Lemak) Pada Beberapa Tempat Pembuangan Limbah Dan Estuari DAM Denpasar. Jurnal Bumi Lestari, Vol 8. hal 122-127.

Droste, R.L. 1997. Theory and Practice of Water and Wastewater Treatment. USA. John Wiley \& Sons, Inc. hal. 547 -595

Fardiaz, S. 1993. Analisis Mikrobiologi Pangan. Raja Grafindo Persada. Jakarta.

Inglis, T.J.J and J.L. Sagripanti. 2006. Environmental Factors that Effect The Survival and Persistance of Burkholderia pseudomallei American Society for Microbiol. 72 (11): 6865-6875. http//aem.asm.org.06/08/2008.

Irianto, A. 2003. Probiotik Akuakultur. Gadjah Mada University Press. 125 hal.

Madigan, M.T., V.M. Martinko, and J. Parker. 2003. Biologi of Microorganism. Eighth Edition. Prentince Hall, Inc., New Jersey.
Prihartono, K, Rasidik, J dan Arie, U. 2000. Mengatasi Permasalahan Budidaya Lele Dumbo. Penebar Swadaya. Jakarta.

Roberts M., M. E. Mercade, M. P. Bosch, J. L. Parra, M. J. Espuny, M. A. Manresa dan J. Guinea. 1989. Effect of Carbon Source on Biosurfactant Production by Pseudomonas aeruginosa 44T1. Biotech Lett. 11:871874.

Saanin, H. 1984. Taksonomi dan Kunci Identifikasi Ikan vol I dan II. Bina Cipta Press. Jakarta.

Salle, A. J. 1991. Fundamental Principles of Bacteriology Fifth Edition. Mc Graw Hill Book Company. Ney York. 812 p.

Sasongko, A. 2001. Biomassa Bakteri Nitrifikasi pada Berbagai Bahan Filter dalam Sistem Resirkulasi Aliran Tertutup dan Pengaruhnya terhadap Kondisi Ikan. Program Studi Ilmu Perairan. IPB. 59 hal.

Sexena, R. K., P. K. Ghost, R. Gupta, W. S. Davidson, S. Bradoo dan R. Gulati. 2004. Microbial Lipase: Potensial Biocatalysts for Tha Future Industry. http:/www.las.ac.in/currsci/jul10/articles 18 .htl. Akses 13/10/09.

Suarsini, E. 2006. Bioremediasi Limbah Cair Rumah Tangga menggunakan Konsorsia Bakteri Indigen yang berpotensi Pereduksi Polutan. Disertasi Program Studi Pendidikan Biologi. Universitas Negeri Malang. 211 hal. 